\title{
Gastrointestinal nematodes in ostriches, Strutbio camelus, in different regions of the state of Rio de Janeiro, Brazil
}

Nematoides gastrintestinais em avestruzes, Struthio camelus, de diferentes regióes do Estado do Rio de Janeiro, Brasil

Nicole Brand Ederli ${ }^{*}$; Francisco Carlos Rodrigues de Oliveira ${ }^{2}$

\author{
${ }^{1}$ Universidade Federal do Pará - UFPA, Campus Universitário do Marajó, Breves, PA, Brasil \\ ${ }^{2}$ Laboratório de Sanidade Animal, Universidade Estadual do Norte Fluminense Darcy Ribeiro - UENF, \\ Campos dos Goytacazes, RJ, Brasil
}

Received January 13, 2015

Accepted April 20, 2015

\begin{abstract}
The ratite group is composed of ostriches, rheas, emus, cassowaries and kiwis. Little research has been done on parasitism in these birds. The aim of this study was to determine the distribution of infections by gastrointestinal nematodes in ostriches in the state of Rio de Janeiro. For this, fecal samples were collected from 192 on 13 farms. From each sample, four grams of feces were used to determine the eggs per gram of feces (EPG) count, by means of the McMaster technique. Part of the feces sample was used for fecal cultures, to identify 100 larvae per sample. The results were subjected to descriptive central trend and dispersion analysis, using confidence intervals at the $5 \%$ error probability level in accordance with the Student t distribution, and Tukey's test with a 95\% confidence interval. The mean EPG in the state was 1,557, and the municipality of Três Rios had the lowest average (62). The city of Campos dos Goytacazes presented the highest mean EPG of all the municipalities analyzed. The northern region presented the highest mean EPG, followed by the southern, metropolitan, coastal lowland and central regions. Libyostrongylus species were observed on all the farms: $L$. douglassii predominated, followed by L. dentatus and Codiostomum struthionis.
\end{abstract}

Keywords: Libyostrongylus douglassii, Libyostrongylus dentatus, Codiostomum struthionis.

\section{Resumo}

O grupo das ratitas é composto pelas avestruzes, emas, emús, cassuares e kiwi. São poucas as pesquisas sobre as parasitoses nessas aves. O objetivo deste estudo foi determinar a distribuição de infecçôes por nematóides gastrintestinais em avestruzes no Estado do Rio de Janeiro. Para tanto, foram coletadas amostras fecais de 192 avestruzes de 13 propriedades. De cada amostra, quatro gramas foram utilizados para a contagem de ovos por grama de fezes (OPG), pela da técnica de McMaster. Parte das fezes foi utilizada para cultivos fecais para identificaçâo de 100 larvas por amostra. Os resultados foram submetidos à análise descritiva de tendência central e de dispersão, utilizando-se o intervalo de confiança ao nível de 5\% de probabilidade de erro de acordo com a distribuiçấo t de Student e teste de Tukey com intervalo de confiança de 95\%. A média de OPG no Estado foi de 1.557, e o município de Três Rios obteve a menor média (62). A cidade de Campos dos Goytacazes teve a maior média de OPG de todos os municípios analisados. A Região Norte teve a maior média de OPG, seguida das regiôes Sul, Metropolitana, Baixada Litorânea e Central. As espécies de Libyostrongylus foram observadas em todas as propriedades, predominando $L$. douglassii, seguido de $L$. dentatus e Codiostomum struthionis.

Palavras-chave: Libyostrongylus donglassii, Libyostrongylus dentatus, Codiostomum struthionis.

*Corresponding author: Nicole Brand Ederli. Universidade Federal do Pará -

UFPA, Campus Universitário do Marajó, Av. Anajás, s/n, Bandeirantes,

CEP 68800-000, Breves, PA, Brasil.

e-mail: ederli@ufpa.br 


\section{Introduction}

Nematodes of the genera Libyostrongylus and Codiostomum were probably introduced into Brazil at the time when ostriches were also introduced, in the 1990s (AICHINGER et al., 2007). This will have been due to deficiencies in sanitary inspection, since there is no standardization by governmental agencies, regarding control over these birds' parasitic diseases, internal marketing or importation. Spreading of some helminth species is favored by their direct life cycle, lack of adequate knowledge among the producers regarding ostrich handling and parasitological control, and trade in these birds without verification of the presence of parasitism. The best procedure for avoiding infection and subsequent economic loss is to prevent introduction of the parasites into the flock (CRAIG \& DIAMOND, 1996). As a biosafety measure, rearing other birds on the same farm needs to be avoided (COOPER, 2005), given that the potential for cross-transmission among other birds, especially among other ratites, has not been determined (HOBERG et al., 1995).

The clinical signs of infection by Libyostrongylus spp. include anorexia, weight loss, anemia (BARTON \& SEWARD, 1993), generalized muscle weakness and lethargy (MUKARATIRWA et al., 2004). The pathogenicity caused by infection by $C$. struthionis is not well known. Oliveira et al. (2009) described an intestinal mucosa thickening where parasites were observed at high concentrations, with nodular areas in the distal third of the infected caeca, as well as hemorrhagic areas abutting small ulcers surrounded by edema. The concentration of $C$. struthionis found in infected birds was directly correlated with the severity of lesions observed in the caeca.

Libyostrongylus Lane, 1923, includes three species: L. douglassii (COBBOLD, 1882) Lane, 1923; L. dentatus Hoberg, Lloyd and Omar, 1995; and L. magnus Gilbert, 1937. All of these can infect the proventriculus of ostriches. Two of these species can be distinguished based on the morphology and morphometry of the posterior end of the infective larvae: $L$. douglassii has a short sheath tail with an acute termination, while $L$. dentatus has a long and filamentous sheath tail (EDERLI et al., 2008a).

The infective larvae of $L$. magnus have not yet been described. The larvae of Libyostrongylus spp. are characterized by a knob on the tip of the tail, which is not observed in the infective larvae of Codiostomum struthionis (EDERLI et al., 2008b). Moreover, the latter species occurs in the caeca of ostriches. The infective larvae of this species are similar to those of $L$. dentatus, with a long and filamentous sheath tail, but can be distinguished based on the morphology of the larval tail tip, which does not present a knob but ends in a finger-like tip (EDERLI et al., 2008b).

Differentiation of these species has become possible because of studies conducted by Ederli et al. (2008a) and Ederli et al. (2008b), which describe the infective larvae of these nematodes. Prior to these studies, the observed low occurrence of $L$. dentatus and C. struthionis may have been due to similarities between the infective larvae in species of these genera. In addition, these two species of Libyostrongylus exhibit different site specificities in the ostrich proventriculus: L. douglassii is located under the koilin layer, whereas $L$. dentatus is found within the koilin layer (EDERLI \& OLIVEIRA, 2009). Prior to the latter study, both of these species had been reported to be located below the koilin layer. Libyostrongylus douglassii is distributed worldwide and has been found in several countries on five continents, excluding Asia and Antarctica (PONCE GORDO et al., 2002). On other hand, $L$. dentatus has only been described in the United States (HOBERG et al., 1995) and Brazil (EDERLI et al., 2008c), while $C$. struthionis has only been reported in Europe (PONCE GORDO et al., 2002) and Brazil (EDERLI et al., 2008b).

The aim of the present study was to determine the distribution of infection by gastrointestinal nematodes in different regions of the state of Rio de Janeiro, Brazil, by means of fecal examination.

\section{Materials and Methods}

Convenience samples of feces from 192 adult ostriches on 13 farms in nine municipalities in the state of Rio de Janeiro were collected soon after the birds defecated. This was done with aid of plastic bags, taking care not to collect feces that had been in contact with the ground. The samplings was done on birds in different paddocks, and at least one sample per paddock was collected. Four grams of feces per bird were used to quantify the number of eggs per gram (EPG), in accordance with Gordon \& Withlock (1939) and four grams of feces were used to perform fecal cultures as described by Bonadiman et al. (2006). From the positive samples, we identified 100 larvae per animal, according to the differences in the posterior end of the larvae as described by Ederli et al. (2008a) and Ederli et al. (2008b), in order to analyze the frequencies of nematode species shed by ostriches.

The sampling was performed in clusters representing the main regions of the state of Rio de Janeiro (municipalities and farms), by selecting farms according to convenience so as to have greater representation and accessibility. The data were analyzed using descriptive central trend and dispersion analysis, using the confidence interval at the $5 \%$ probability level in accordance with the Student t distribution. The Tukey test was used to compare the percentage values of each nematode species by means of analysis on the larvae, per farm, municipality and region. All calculations were performed using the SAEG program, version 9.1.

\section{Results}

In 13 ostrich-breeding farms in the state of Rio de Janeiro, the observed frequency of infected ostriches was 93\% (179 out of 192 samples) (Table 1). The eggs presented the typical characteristics of Strongylida. The mean EPG in the state of Rio de Janeiro was 1,557.46, ranging from zero to 19,600. The municipality of Três Rios (central region) had the lowest mean, of 61.76, with a range from zero to 200. Campos dos Goytacazes (northern region) had the highest mean EPG, of 3,825.00, with a range from zero to 6,100 . The northern region of the state had the highest mean EPG $(3,190$, ranging from zero to 10,050$)$, followed by the southern region (2,433.33, ranging from 800 to 8,400$)$, metropolitan region (2,033.30, ranging from 100 to 19,600$)$, coastal lowland region $(1,239.38$, ranging from zero to 16,900$)$ and central region (61.76, ranging from zero to 200). The results per farm, municipality and region are presented in Table 1. 
Table 1. Eggs per gram of feces (EPG) counts and mean proportions of nematode species according to larvae identified from the feces of ostriches (Struthio camelus) in the state of Rio de Janeiro, Brazil. Mean \pm SE, followed by minimum and maximum values in parentheses and confidence interval (CI).

\begin{tabular}{|c|c|c|c|c|c|c|c|c|}
\hline \multirow{2}{*}{$\begin{array}{c}\text { Regions/ } \\
\text { Cities }\end{array}$} & \multirow{2}{*}{ Farm } & \multirow{2}{*}{ Flock } & \multirow{2}{*}{$\begin{array}{l}\text { No of fecal } \\
\text { samples }\end{array}$} & \multirow{2}{*}{$\begin{array}{l}\text { Positive } \\
\text { samples }\end{array}$} & \multirow{2}{*}{ EPG } & \multicolumn{3}{|c|}{ Infective larvae (\%) } \\
\hline & & & & & & L. douglassii & L. dentatus & C. struthionis \\
\hline \multirow[t]{2}{*}{ North } & & 163 & 33 & 31 & $3,190.00 \pm 592.24(50-10,050)$ & $86.28 \pm 2.37(56-100)$ & $13.72 \pm 2.37(0-44)$ & $\mathbf{0}^{\mathrm{C}}$ \\
\hline & & & & & $\mathrm{CI}=1,211.26$ & $\mathrm{CI}=4.84^{\mathrm{A}}$ & $\mathrm{CI}=4.84^{\mathrm{B}}$ & \\
\hline \multirow{4}{*}{$\begin{array}{l}\text { Campos dos } \\
\text { Goytacazes }\end{array}$} & & 10 & 5 & 4 & $4,825.00 \pm 566.24(3,400-6,100)$ & $94.47 \pm 3.87(83-100)$ & $5.53 \pm 3.87(0-17)$ & $0^{\mathrm{B}}$ \\
\hline & & & & & $\mathrm{CI}=1,109.81$ & $\mathrm{CI}=12.33^{\mathrm{A}}$ & $\mathrm{CI}=12.30^{\mathrm{B}}$ & \\
\hline & 1 & 10 & 5 & 4 & $4,825.00 \pm 566.24(3,400-6,100)$ & $94.47 \pm 3.87(83-100)$ & $5.53 \pm 3.87(0-17)$ & $0^{\text {B }}$ \\
\hline & & & & & $\mathrm{CI}=1,109.81$ & $\mathrm{CI}=12.33^{\mathrm{A}}$ & $\mathrm{CI}=12.30^{\mathrm{B}}$ & \\
\hline \multirow{8}{*}{$\begin{array}{l}\text { São Francisco } \\
\text { do Itabapoana }\end{array}$} & & 153 & 28 & 27 & $2,938.46 \pm 666.75(50-10,050)$ & $85.02 \pm 2.60(56-100)$ & $14.98 \pm 2.60(0-44)$ & $0^{\mathrm{C}}$ \\
\hline & & & & & $\mathrm{CI}=1,373.20$ & $\mathrm{CI}=5.35^{\mathrm{A}}$ & $\mathrm{CI}=5.35^{\mathrm{B}}$ & \\
\hline & 2 & 98 & 15 & 15 & $4,728.57 \pm 993.70(100-10,050)$ & $81.36 \pm 2.86(60-97)$ & $18.64 \pm 2.87(3-40)$ & $0^{\mathrm{C}}$ \\
\hline & & & & & $\mathrm{CI}=2,146.76$ & $\mathrm{CI}=6.17^{\mathrm{A}}$ & $\mathrm{CI}=6.17^{\mathrm{B}}$ & \\
\hline & 3 & 45 & 10 & 9 & $677.78 \pm 237.77(50-1,900)$ & $93.7 \pm 4.75(56-100)$ & $6.93 \pm 4.75(4-44)$ & $0^{\mathrm{B}}$ \\
\hline & & & & & $\mathrm{CI}=548.30$ & $\mathrm{CI}=10.95^{\mathrm{A}}$ & $\mathrm{CI}=10.95^{\mathrm{B}}$ & \\
\hline & 4 & 10 & 3 & 3 & $1,366.67 \pm 1,072.90(100-3,500)$ & $78.00 \pm 7.64(68-93)$ & $22.00 \pm 7.64(7-32)$ & $0^{\mathrm{B}}$ \\
\hline & & & & & $\mathrm{CI}=4,616.31$ & $\mathrm{CI}=32.86^{\mathrm{A}}$ & $\mathrm{CI}=32.86^{\mathrm{B}}$ & \\
\hline \multirow{2}{*}{$\begin{array}{l}\text { Littoral } \\
\text { Lowland }\end{array}$} & & 776 & 121 & 111 & $1,239.38 \pm 231.18(50-16,900)$ & $81.46 \pm 1.95(0-100)$ & $16.69 \pm 1.89(0-100)$ & $1.85 \pm 0.37(0-20)$ \\
\hline & & & & & $\mathrm{CI}=458.05$ & $\mathrm{CI}=3.87^{\mathrm{A}}$ & $\mathrm{CI}=3.74^{\mathrm{B}}$ & $\mathrm{CI}=\mathbf{0 . 7 2}{ }^{\mathrm{C}}$ \\
\hline \multirow[t]{4}{*}{ Araruama } & & 32 & 18 & 15 & $640.00 \pm 207.83(50-2,600)$ & $81.64 \pm 3.69(50-99)$ & $16.55 \pm 3.52(1-48)$ & $1.81 \pm 0.67(0-8)$ \\
\hline & & & & & $\mathrm{CI}=445.76$ & $\mathrm{CI}=7.92^{\mathrm{A}}$ & $\mathrm{CI}=7.54^{\mathrm{B}}$ & $\mathrm{CI}=1.44^{\mathrm{C}}$ \\
\hline & 5 & 32 & 18 & 15 & $640.00 \pm 207.83(50-2,600)$ & $81.64 \pm 3.69(50-99)$ & $16.55 \pm 3.52(1-48)$ & $1.81 \pm 0.67(0-8)$ \\
\hline & & & & & $\mathrm{CI}=445.76$ & $\mathrm{CI}=7.92^{\mathrm{A}}$ & $\mathrm{CI}=7.54^{\mathrm{B}}$ & $\mathrm{CI}=1.44^{\mathrm{C}}$ \\
\hline \multirow[t]{6}{*}{ Cabo Frio } & & 246 & 33 & 29 & $946.55 \pm 460.90(50-13,500)$ & $82.51 \pm 3.15(19-100)$ & $13.94 \pm 3.03(0-81)$ & $3.55 \pm 1.03(0-20)$ \\
\hline & & & & & $\mathrm{CI}=944.10$ & $\mathrm{CI}=6.46^{\mathrm{A}}$ & $\mathrm{CI}=6.20^{\mathrm{B}}$ & $2.11^{\mathrm{C}}$ \\
\hline & 6 & 6 & 6 & 6 & $350.00 \pm 102.47(100-700)$ & $70.33 \pm 11.32(19-93)$ & $29.67 \pm 11.32(7-81)$ & $0^{\mathrm{B}}$ \\
\hline & & & & & $\mathrm{CI}=263.41$ & $\mathrm{CI}=29.11^{\mathrm{A}}$ & $\mathrm{CI}=29.11^{\mathrm{B}}$ & \\
\hline & 7 & 240 & 27 & 23 & $1,102.17 \pm 578.74(50-13,500)$ & $85.69 \pm 2.47(59-100)$ & $9.84 \pm 1.84(0-31)$ & $4.48 \pm 1.23(0-20)$ \\
\hline & & & & & $\mathrm{CI}=1,200.24$ & $\mathrm{CI}=5.13^{\mathrm{A}}$ & $\mathrm{CI}=3.82^{\mathrm{B}}$ & $\mathrm{CI}=2.55^{\mathrm{B}}$ \\
\hline \multirow{6}{*}{$\begin{array}{l}\text { Casimiro de } \\
\text { Abreu }\end{array}$} & & 168 & 35 & 33 & $408.82 \pm 125.73(50-3,500)$ & $69.50 \pm 4.86(0-100)$ & $28.34 \pm 4.78(0-100)$ & $2.15 \pm 0.68(0-15)$ \\
\hline & & & & & $\mathrm{CI}=255.80$ & $\mathrm{CI}=9.89^{\mathrm{A}}$ & $9.73^{\mathrm{B}}$ & $1.39^{\mathrm{C}}$ \\
\hline & 8 & 120 & 21 & 20 & $554.76 \pm 195.85(50-3,300)$ & $71.80 \pm 7.05(0-100)$ & $28.20 \pm 7.05(0-100)$ & $0^{\mathrm{C}}$ \\
\hline & & & & & $\mathrm{CI}=408.53$ & $\mathrm{CI}=14.7^{\mathrm{A}}$ & $\mathrm{CI}=14.7^{\mathrm{B}}$ & \\
\hline & 9 & 48 & 14 & 13 & $173.08 \pm 54.19(50-600)$ & $65.79 \pm 5.87(34-96)$ & $28.57 \pm 5.57(2-65)$ & $5.63 \pm 1.32(0-15)$ \\
\hline & & & & & $\mathrm{CI}=118.07$ & $\mathrm{CI}=12.80^{\mathrm{A}}$ & $\mathrm{CI}=12.14^{\mathrm{B}}$ & $\mathrm{CI}=2.87^{\mathrm{C}}$ \\
\hline \multirow[t]{4}{*}{ Saquarema } & & 330 & 35 & 34 & $2,545.71 \pm 569.55(50-16,900)$ & $92.11 \pm 1.27(69-100)$ & $7.71 \pm 1.20(0-26)$ & $0.17 \pm 0.14(0-5)$ \\
\hline & & & & & $\mathrm{CI}=1,157.47$ & $\mathrm{CI}=2.58^{\mathrm{A}}$ & $\mathrm{CI}=2.44^{\mathrm{B}}$ & $\mathrm{CI}=0.29^{\mathrm{C}}$ \\
\hline & 10 & 330 & 35 & 34 & $2,545.71 \pm 569.55(50-16,900)$ & $92.11 \pm 1.27(69-100)$ & $7.71 \pm 1.20(0-26)$ & $0.17 \pm 0.14(0-5)$ \\
\hline & & & & & $\mathrm{CI}=1,157.47$ & $\mathrm{CI}=2.58^{\mathrm{A}}$ & $\mathrm{CI}=2.44^{\mathrm{B}}$ & $\mathrm{CI}=0.29^{\mathrm{C}}$ \\
\hline \multirow[t]{2}{*}{ Central } & & 180 & 17 & 16 & $61.76 \pm 9.12(50-200)$ & $11.21 \pm 3.88(0-61)$ & $88.79 \pm 3.88(39-100)$ & $0^{\mathrm{C}}$ \\
\hline & & & & & $\mathrm{CI}=19.34$ & $\mathrm{CI}=8.23^{\mathrm{A}}$ & $\mathrm{CI}=8.23^{\mathrm{B}}$ & \\
\hline \multirow[t]{4}{*}{ Três Rios } & & 180 & 17 & 16 & $61.76 \pm 9.12(50-200)$ & $11.21 \pm 3.88(0-61)$ & $88.79 \pm 3.88(39-100)$ & $0^{\mathrm{C}}$ \\
\hline & & & & & $\mathrm{CI}=19.34$ & $\mathrm{CI}=8.23^{\mathrm{A}}$ & $\mathrm{CI}=8.23^{\mathrm{B}}$ & \\
\hline & 11 & 180 & 17 & 16 & $61.76 \pm 9.12(50-200)$ & $11.21 \pm 3.88(0-61)$ & $88.79 \pm 3.88(39-100)$ & $0^{\mathrm{C}}$ \\
\hline & & & & & $\mathrm{CI}=19.34$ & $\mathrm{CI}=8.23^{\mathrm{A}}$ & $\mathrm{CI}=8.23^{\mathrm{B}}$ & \\
\hline \multirow[t]{2}{*}{ South } & & 10 & 6 & 6 & $2,433.33 \pm 1,199.07(800-8,400)$ & $92.08 \pm 2.07(86-100)$ & $6.43 \pm 1.78(0-13)$ & $1.50 \pm 0.96(0-6)$ \\
\hline & & & & & $\mathrm{CI}=3,082.32$ & $\mathrm{CI}=5.32^{\mathrm{A}}$ & $\mathrm{CI}=4.57^{\mathrm{B}}$ & $\mathrm{CI}=2.46^{\mathrm{B}}$ \\
\hline \multirow[t]{4}{*}{ Valença } & & 10 & 6 & 6 & $2,433.33 \pm 1,199.07(800-8,400)$ & $92.08 \pm 2.07(86-100)$ & $6.43 \pm 1.78(0-13)$ & $1.50 \pm 0.96(0-6)$ \\
\hline & & & & & $\mathrm{CI}=3,082.32$ & $\mathrm{CI}=5.32^{\mathrm{A}}$ & $\mathrm{CI}=4.57^{\mathrm{B}}$ & $\mathrm{CI}=2.46^{\mathrm{B}}$ \\
\hline & 12 & 10 & 6 & 6 & $2,433.33 \pm 1,199.07(800-8,400)$ & $92.08 \pm 2.07(86-100)$ & $6.43 \pm 1.78(0-13)$ & $1.50 \pm 0.96(0-6)$ \\
\hline & & & & & $\mathrm{CI}=3,082.32$ & $\mathrm{CI}=5.32^{\mathrm{A}}$ & $\mathrm{CI}=4.57^{\mathrm{B}}$ & $\mathrm{CI}=2.46^{\mathrm{B}}$ \\
\hline Metropolitan & & 20 & 15 & 15 & & $78.05 \pm 3.61(46-100)$ & $14.47 \pm 2.92(0-38)$ & $7.48 \pm 1.84(0-20)$ \\
\hline & & & & & $\mathrm{CI}=2,719.15$ & $\mathrm{CI}=7.74^{\mathrm{A}}$ & $\mathrm{CI}=6.26^{\mathrm{B}}$ & $\mathrm{CI}=3.95^{\mathrm{B}}$ \\
\hline
\end{tabular}

Proportions mean in the lines with the same superscript letters do not differ significantly by Tukey test with a confidence interval of $95 \%$. P value $<0.05$. 
Table 1. Continued...

\begin{tabular}{|c|c|c|c|c|c|c|c|c|}
\hline \multirow{2}{*}{$\begin{array}{c}\text { Regions/ } \\
\text { Cities }\end{array}$} & \multirow{2}{*}{ Farm } & \multirow{2}{*}{ Flock } & \multirow{2}{*}{$\begin{array}{c}\text { No of fecal } \\
\text { samples }\end{array}$} & \multirow{2}{*}{$\begin{array}{l}\text { Positive } \\
\text { samples }\end{array}$} & \multirow{2}{*}{ EPG } & \multicolumn{3}{|c|}{ Infective larvae (\%) } \\
\hline & & & & & & L. douglassii & L. dentatus & C. struthionis \\
\hline \multirow{4}{*}{$\begin{array}{l}\text { Miguel } \\
\text { Pereira }\end{array}$} & & 20 & 15 & 15 & $2,033.33 \pm 1,267.79(100-19,600)$ & $78.05 \pm 3.61(46-100)$ & $14.47 \pm 2.92(0-38)$ & $7.48 \pm 1.84(0-20)$ \\
\hline & & & & & $\mathrm{CI}=2,719.15$ & $\mathrm{CI}=7.74^{\mathrm{A}}$ & $\mathrm{CI}=6.26^{\mathrm{B}}$ & $\mathrm{CI}=3.95^{\mathrm{B}}$ \\
\hline & 13 & 20 & 15 & 15 & $2,033.33 \pm 1,267.79(100-19,600)$ & $78.05 \pm 3.61(46-100)$ & $14.47 \pm 2.92(0-38)$ & $7.48 \pm 1.84(0-20)$ \\
\hline & & & & & $\mathrm{CI}=2,719.15$ & $\mathrm{CI}=7.74^{\mathrm{A}}$ & $\mathrm{CI}=6.26^{\mathrm{B}}$ & $\mathrm{CI}=3.95^{\mathrm{B}}$ \\
\hline \multirow[t]{2}{*}{ TOTAL } & 13 & 1,149 & 192 & 179 & $1,557.46 \pm 241.54(50-19,600)$ & $75.73 \pm 2.07(0-100)$ & $22.45 \pm 2.07(0-100)$ & $1.83 \pm 0.31(0-20)$ \\
\hline & & & & & $\mathrm{CI}=423.35$ & $\mathrm{CI}=4.08^{\mathrm{A}}$ & $\mathrm{CI}=4.08^{\mathrm{B}}$ & $\mathrm{CI}=0.61^{\mathrm{C}}$ \\
\hline
\end{tabular}

Proportions mean in the lines with the same superscript letters do not differ significantly by Tukey test with a confidence interval of $95 \%$. P value $<0.05$.

Municipalities with mean EPG greater than 2,500 (Campos dos Goytacazes, São Francisco do Itabapoana and Saquarema) differed statistically from those with EPG less than 650 (Araruama, Casimiro de Abreu and Três Rios). Those with mean EPG near the median, ranging from 940 to 2400 (Cabo Frio, Valença and Miguel Pereira) did not differ statistically from other municipalities.

An analysis on the infective larvae recovered from fecal cultures confirmed the presence of $L$. douglassii, L. dentatus and C. struthionis, which infect ostrich flocks in the state of Rio de Janeiro, Brazil (Figure 1). Species of the genus Libyostrongylus were observed on all 13 farms analyzed. However, C. struthionis was observed only on six farms, with low proportions that never exceeded $7.5 \%$. Infections of C. struthionis were not present in the northern region, where four farms in two municipalities (Campos dos Goytacazes and São Francisco do Itabapoana) were examined, or in the central region, where fecal samples from a single farm in the municipality of Três Rios were examined. In addition, $C$. struthionis was not identified on one of the two farms that we analyzed in the municipality of Cabo Frio, which is in the coastal lowland region, where ostriches on six farms were analyzed. On the single farm analyzed in the municipality of Saquarema, C. struthionis was observed at an extremely low proportion $(0.17 \%)$, such that only two ostriches out of 35 were positive for this species, with counts of one and five larvae out of 100. In all the birds in which C. struthionis was diagnosed, infection by $L$. douglassii and L. dentatus was also present. Among the positive samples, only two birds were positive only for $L$. dentatus, and both of these were in Três Rios (central region).

Species of Libyostrongylus were found on all the 13 farms analyzed, with proportions ranging from 0 to $100 \%$ (Table 1). There were significant differences in the proportions of $L$. douglassii, $L$. dentatus and $C$. struthionis, such that $L$. douglassii was the most frequent species and $C$. struthionis the least frequent in the state of Rio de Janeiro. However, in the municipality of Três Rios (central region), there were unusual proportions of these three species, such that we observed a proportion of $L$. dentatus that was statistically greater than that of $L$. douglassii (Table 1 ). In this municipality, no C. struthionis larvae were present in ostrich feces.

With the exception of the farm located in the municipality of Três Rios (central Region), which had a mean L. douglassii proportion of 11.21, all the other farms presented mean proportions ranging from 65.7 to 94.4 . The low proportion of $L$. douglassii and high

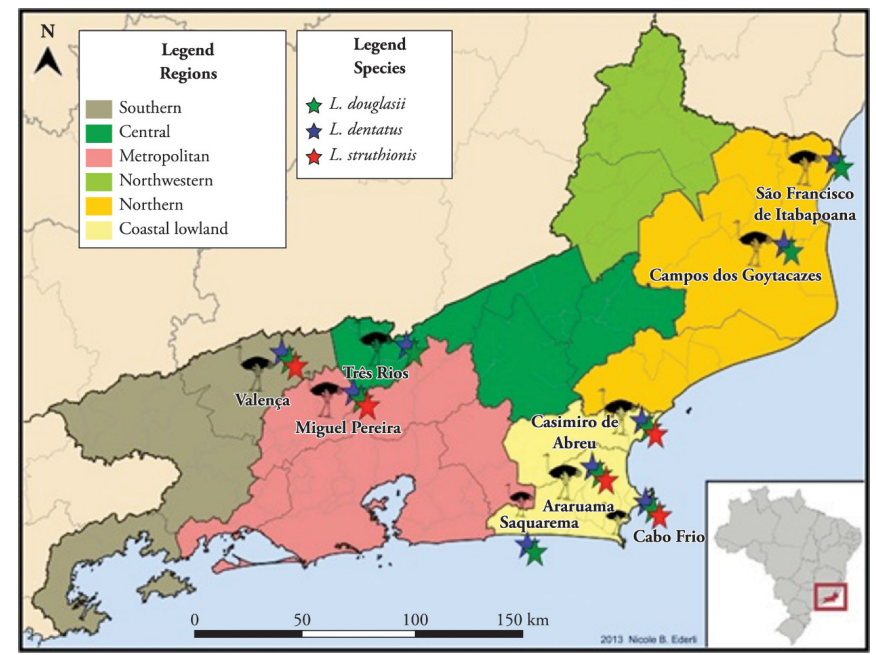

Figure 1. Map of the state of Rio de Janeiro, Brazil, including regions and cities, showing the distribution of gastrointestinal nematode infections.

proportion of $L$. dentatus observed on the farm in the municipality of Três Rios was statistically different from all other farms.

The metropolitan and southern regions of the state of Rio de Janeiro did not show any statistical difference between the proportions of L. dentatus and C. struthionis (Table 1). Although there was a statistical difference between the proportions of these three species in the northern region, some farms (one in Campos dos Goytacazes and two in São Francisco do Itabapoana) did not present any statistical difference in the proportions of C. struthionis and $L$. dentatus. The same was observed on one farm in the municipality of Cabo Frio (coastal lowland region).

\section{Discussion}

The results presented here describe occurrences of gastrointestinal nematodes in ostriches in the state of Rio de Janeiro, Brazil. These infections are present on ostrich farms in the state of Rio de Janeiro, with predominance of $L$. douglassii, followed by $L$. dentatus and $C$. struthionis (Table 1). This pattern was also observed by Andrade et al. (2011), based on a study in which fecal examination was performed on ostriches on 17 farms distributed across different Brazilian states, including 42 samples from only three farms in the state of Rio de Janeiro. They did not observe any larvae in the feces 
from four farms, including one in the state of Ceará (where only one farm analyzed), one in the state of Rio de Janeiro (three farms analyzed) and two in the state of Paraná (four farms analyzed). However, the authors did not identify the municipalities where the samples were collected. Andrade et al. (2011) did not perform EPG counts, because they received fecal samples sent by express mail, thus constraining this procedure. In our study, we analyzed the proportions of infective larvae of $L$. douglassii, $L$. dentatus and C. struthionis. Furthermore, we determined the parasite load in the Rio de Janeiro flock, thus showing the actual situation of this parasitosis in this state.

In our study, Libyostrongylus species were present on all the farms examined, while $C$. struthionis was not found only in the northern or central regions of the state of Rio de Janeiro. The frequency of $L$. dentatus infection statistically exceeded that of $L$. douglassii on one farm in the municipality of Três Rios. Andrade et al. (2011) also observed higher frequency of $L$. dentatus than of L. douglassii only on one farm, in the state of São Paulo, with mean percentages of infective larvae of $L$. dentatus and L. douglassii of $57 \%$ and $13 \%$, respectively. In addition, on this same farm, the mean percentage of $C$. struthionis was also higher than that of $L$. douglassii. This was not observed on any farm in our study. The standard-deviations relating to the EPG analyses were higher than the means. This shows that there was great variability in the EPG counts from the flocks in the state of Rio de Janeiro.

These parasites were introduced into Brazil through the importation of ostriches in 1995, with the first imports of birds from the United States and Spain (AICHINGER et al., 2007). Today, these parasites are widely distributed and display a high level of adaptation within this country, with prevalence rates of $100 \%$. However, Libyostrongylus dentatus and C. struthionis are only infrequently reported, probably because until recently they could only be properly identified via necropsy on the birds, in order to collect and identify adult parasites. Libyostrongylus dentatus has exclusively been reported in the United States (HOBERG et al., 1995) and Brazil (EDERLI et al., 2008c), while C. struthionis has only been reported in Europe (PONCE GORDO et al., 2002) and Brazil (EDERLI et al., 2008b). In contrast, L. douglassii is distributed worldwide and has been found in South Africa (MALAN et al., 1988; FOCKEMA et al., 1985; REINECKE, 1983), Australia (BARTON \& SEWARD, 1993; BUTTON et al., 1993; MORE, 1996), the United States (HOBERG et al., 1995), Italy (PINTORI et al., 2000), Scotland (PENNYCOTT \& PATTERSON, 2001), Spain, Belgium, Portugal and the Netherlands (PONCE GORDO et al., 2002), Sweden (JANSSON et al., 2002), New Zealand (MACKERETH, 2004; MCKENNA, 2005), Zimbabwe (MUKARATIRWA et al., 2004) and Brazil (BONADIMAN et al., 2006; EDERLI et al., 2008a, c).

Recently, Fagundes et al. (2012) described the seasonality and occurrence of C. struthionis on two farms in the municipalities of Areal and Itaboraí in the state of Rio de Janeiro, in which they analyzed 237 and 195 samples, respectively. However, the images of the posterior end of the infective larvae reported by Fagundes et al. (2012) are clearly from $L$. dentatus, since the larvae have a knob on the tip of the tail and a long, filamentous tail sheath. Thus, the seasonality described by Fagundes et al. (2012) for C. struthionis is likely based on mixed infection, since we too have identified mixed infections of Libyostrongylus spp. and C. struthionis in the state of Rio de Janeiro, including these same regions (metropolitan and central). In these regions, we identified farms that were negative for infection and that displayed low frequencies of C. struthionis, as observed in other regions of the state of Rio de Janeiro (Table 1). This observation was also made by Andrade et al. (2011) in relation to several regions of Brazil, in which they observed C. struthionis on only three of the 17 farms analyzed.

In Brazil, commercial ostrich breeding is becoming common, but not widely distributed throughout the country, because the Brazilian Institute for the Environment and Natural Resources (IBAMA) regulates breeding.

Breeding of emus (Dromaius novaehollandiae), another ratite bird, especially in the central-western region of Brazil, has recently been started in this country. The potential for cross-transmission of these parasites to other birds, including ratites in particular, has not yet been investigated. There is a report describing these parasites in emus in Sweden (JANSSON \& CHRISTENSSON, 2000), but this observation has not been confirmed by identification of infective larvae or adult nematodes because these authors reported eggs in bird feces. Finally, it is also important to examine possible infection by these nematodes in the rhea, a native bird of South America.

Thus, the present study demonstrates that gastrointestinal nematodes infecting ostriches are widely distributed in the state of Rio de Janeiro, occurring in an enzootic form in the flock with a high parasite load, in which $L$. douglassii predominates, followed by $L$. dentatus and $C$. struthionis. These results demonstrate that these exotic parasites have attained good adaptation to the region studied and possibly to the whole country.

\section{Acknowledgements}

This study was supported by the Coordination Office for Improvement of Higher-Education Personnel (Coordenação de Aperfeiçoamento de Pessoal de Nível Superior, CAPES), the National Council for Scientific and Technological Development (Conselho Nacional de Desenvolvimento Científico e Tecnológico, $\mathrm{CNPq}$ ) and the Carlos Chagas Filho Foundation of Rio de Janeiro (FAPERJ).

\section{References}

Aichinger A, Martins NR, Souza JD, Resende JS, Muniz R, Ferreira WM. O avestruz no Brasil e no mundo. Rev Vet Zootec Minas 2007; 27(1): 36-39.

Andrade JG, Lelis RT, Damatta RA, Santos CP. Occurrence of nematodes and anthelmintic management of ostrich farms from different Brazilian states: Libyostrongylus douglassii dominates mixed infections. Vet Parasitol 2011; 178(1-2): 129-133. http://dx.doi.org/10.1016/j.vetpar.2010.12.032. PMid:21247703.

Barton NJ, Seward DA. Detection of Libyostrongylus douglassi in ostriches in Australia. Aust Vet J 1993; 70(1): 31-32. http://dx.doi. org/10.1111/j.1751-0813.1993.tb00796.x. PMid:8460985.

Bonadiman SF, Ederli NB, Soares AKP, Moraes AH No, Santos CP, Damatta RA. Occurrence of Libyostrongylus sp. (Nematoda) in ostriches 
(Struthio camelus Linnaeus, 1758) from the north region of the state of Rio de Janeiro, Brazil. Vet Parasitol 2006; 137(1-2): 175-179. http:// dx.doi.org/10.1016/j.vetpar.2005.12.018. PMid:16448757.

Button C, Barton NJ, Veale PI, Overend DJ. A survey of Libyostrongylus douglassi on ostrich farms in eastern Victoria. Aust Vet J 1993; 70(2): 76. http://dx.doi.org/10.1111/j.1751-0813.1993.tb15152.x. PMid:8457182.

Cobbold TS. New entozoon from the ostrich. J Linn Soc Lond 1882; 16(91): 184-188. http://dx.doi.org/10.1111/j.1096-3642.1882.tb02280.x.

Cooper RG. Bacterial, fungal and parasitic infections in the ostrich (Struthio camelus var. domesticus). Anim Sci J2005; 76(2): 97-106. http:// dx.doi.org/10.1111/j.1740-0929.2005.00243.x.

Craig TM, Diamond PL. Parasites of ratites. In: Tully TN, Shane SN, editors. Ratite management, medicine and surgery. Florida: Kreiger Publishing Company; 1996. p. 115-126.

Ederli NB, Oliveira FC, Lopes CWG, Damatta RA, Santos CP, Azevedo Rodrigues ML. Morphological diagnosis of infective larvae of Libyostrongylus douglassii (Cobbold, 1882) Lane, 1923 and L. dentatus Hoberg, Lloyd and Omar, 1995 (Nematoda: Trichostrongylidae) of ostriches. Vet Parasitol 2008a; 155(3-4): 323-327. http://dx.doi.org/10.1016/j.vetpar.2008.04.023. PMid:18565673.

Ederli NB, Oliveira FC, Rodrigues ML. Further study of Codiostomum struthionis (Horst, 1885) Railliet and Henry, 1911 (Nematoda, Strongylidae) parasite of ostriches (Struthio camelus Linnaeus, 1758) (Aves, Struthioniformes). Vet Parasitol 2008b; 157(3-4): 275-283. http:// dx.doi.org/10.1016/j.vetpar.2008.07.018. PMid:18774651.

Ederli NB, Bonadiman SF, Moraes AH No, DaMatta RA, Paula Santos C. Mixed infection by Libyostrongylus douglassii and L. dentatus (Nematoda: Trichostrongylidae) in Struthio camelus (Ratites: Struthioniformes) from Brazil with further morphological characterization of adults. Vet Parasitol 2008c; 151(2-4): 227-232. http://dx.doi.org/10.1016/j.vetpar.2007.11.009. PMid: 18155840 .

Ederli NB, Oliveira FCR. Differential localization of Libyostrongylus douglassii (Cobbold, 1882) Lane, 1923 and L. dentatus Hoberg, Lloyd, and Omar, 1995 (Nematoda: Trichostrongylidae) in ostrich (Struthio camelus Linnaeus, 1758) proventriculi. J Parasitol 2009; 95(3): 757-759. http://dx.doi.org/10.1645/GE-1853.1. PMid:18990000.

Fagundes TF, Soleiro CA, de Menezes RC. The occurrence of Codiostomum struthionis in ostriches (Struthio camelus) of different ages and during the dry and rainy seasons at two farms in the State of Rio de Janeiro, Brazil. Vet Parasitol 2012; 183(3-4): 269-273. http://dx.doi.org/10.1016/j. vetpar.2011.07.041. PMid:21856078.

Fockema A, Malan FS, Cooper GG, Visser E. Anthelmintic efficacy of fenbendazole against Libyostrongylus douglassi and Houttuynia struthionis in ostriches. J S Afr Vet Assoc 1985; 56(1): 47-48. PMid:3999107.
Gordon NM, Withlock HV. A new technique for counting nematode eggs in sheep faeces. J Counc Sci Ind Res 1939; 12(1): 50-52.

Hoberg EP, Lloyd S, Omar H. Libyostrongylus dentatus n. sp. (Nematoda: Trichostrongylidae) from ostriches in North America, with comments on the genera Libyostrongylus and Paralibyostrongylus. J Parasitol 1995; 81(1): 85-93. http://dx.doi.org/10.2307/3284011. PMid:7876985.

Jansson DS, Christensson D. Gastrointestinala parasiter hos strutsfåglar i Sverige. Swed Vet J 2000; 52(2): 621-626.

Jansson DS, Christensson DA, Christensson BE. Winter survival in Sweden of L(3)-stage larvae of the ostrich wireworm Libyostrongylus douglassii. Vet Parasitol 2002; 106(1): 69-74. http://dx.doi.org/10.1016/ S0304-4017(02)00033-X. PMid:11992712.

Mackereth G. Libyostrongylus douglassii in New Zealand ostriches. Surveillance 2004; 31(3): 14-16.

Malan FS, Gruss B, Roper NA, Ashburner AJ, du Plessis CA. Resistance of Libyostrongylus douglassi in ostriches to levamisole. J S Afr Vet Assoc 1988; 59(4): 202-203. PMid:3210219.

McKenna PB. Libyostrongylus infections in ostriches: a brief review with particular reference to their detection in New Zealand. NZ Vet J 2005; 53(5): 267-270. http://dx.doi.org/10.1080/00480169.2005.36559. PMid:16220116.

More SJ. The performance of farmed ostrich hens in eastern Australia. Prev Vet Med 1996; 29(2): 107-120. http://dx.doi.org/10.1016/S01675877(96)01063-X.

Mukaratirwa S, Cindzi ZM, Maononga DB. Prevalence of Libyostrongylus douglassii in commercially reared ostriches in the highveld region of Zimbabwe. J Helminthol 2004; 78(4): 333-336. http://dx.doi.org/10.1079/ JOH2004246. PMid:15575991.

Oliveira FC, Ederli NB, Lopes CWG, Rodrigues ML. Pathological findings in the caeca of naturally infected ostriches, Struthio camelus Linnaeus, 1758 (Aves, Struthionidae) parasitized by Codiostomum struthionis (Horst, 1885) Railliet and Henry, 1911 (Nematoda, Strongylidae). Vet Parasitol 2009; 165(1-2): 175-178. http://dx.doi.org/10.1016/j.vetpar.2009.06.034. PMid:19647369.

Pennycott T, Patterson T. Gastrointestinal parasites in ostriches (Struthio camelus). Vet Rec 2001; 148(5): 155-156. PMid:11271923.

Pintori A, Scala A, Giannetto S, Mascia M, Rosa R. Parasitosis of ostriches (Struthio camelus) in Sardinia (Italy). Acta Parasitol 2000; 45(30): 164.

Ponce Gordo F, Herrera S, Castro AT, García Durán B, Martínez Díaz RA. Parasites from farmed ostriches (Struthio camelus) and rheas (Rhea americana) in Europe. Vet Parasitol 2002; 107(1-2): 137-160. http:// dx.doi.org/10.1016/S0304-4017(02)00104-8. PMid:12072221.

Reinecke RK. Veterinary helminthology. Durban: Butterworth; 1983295 p. 